\title{
The Postnatal Hypotransferrinemia of Early Preterm Newborn Infants
}

\author{
SAMUEL GALET AND HERBERT M. SCHULMAN (26) \\ Lady Davis Institute for Medical Research, Jewish General Hospital and Biology Department, McGill University, \\ Montreal, Quebec, Canada \\ HARRY BARD \\ Perinatal Service, Centre de Recherche, Hospital Ste. Justine, and Department de Pediatrie, Universite de \\ Montreal, Montreal, Quebec, Canada
}

\section{Extract}

Preterm newborns were found to be markedly hypotransferrinemic when compared with normal term infants. At birth the concentration of transferrin in sera from preterm infants of gestational age equal to or less than 32 weeks is $45 \%$ of that found in normal term infant sera. The preterm infant transferrin levels slowly rise so that 7-8 weeks after birth they are $78 \%$ of the level found in the sera of normal term infants. We also found that the serum transferrin concentrations at birth correlate with gestational age. Therefore, the transferrin levels postnatally in early preterm infants reflect postconceptional rather than postnatal age.

\section{Speculation}

Since we found that early preterm newborns are markedly hypotransferrinemic, administration of iron to such infants during their first few postnatal months may be contraindicated. Harmful side effects of iron during this period might include an increased susceptibility to infection because of the known bacteriostatic and fungistatic activities of iron-free transferrin.

The serum iron-binding protein transferrin has been known to possess bacteriostatic and fungistatic activities since it was first described by Schade and Caroline in 1946 (20). Subsequently, the function of transferrin as an iron transport protein has been well established (14), but the role of transferrin in nonspecific immunity still remains to be clarified completely.

Nevertheless, the results of many recent studies have reiterated the bacteriostatic properties of serum transferrin in vitro and in vivo in experimental animals. It has been concluded that iron-free transferrin is bacteriostatic because it can compete successfully with many pathogens for iron when this essential nutrient is present in limiting amounts $(4-7,10,19,22)$. Such a mechanism of bacteriostasis is reasonable considering the extraordinarily high affinity which transferrin has for iron (1).

In the normal human, serum transferrin is only $30-40 \%$ saturated with iron. Many pathologic states in which the saturation of transferrin with iron is elevated are associated with an increased occurrence of infection $(7,23,24)$. When children with kwashiorkor, whose transferrin levels are severely depressed (17), are given iron therapy before their transferrin levels become normal, a high incidence of death from infection ensues (18). Taken together, these various clinical observations support the concept that transferrin may play a role in nonspecific immunity to bacterial and fungal infections.

The transferrin in sera of newborns is highly saturated with iron (21). Since early preterm newborn infants are particularly suscepti- ble to infection, the aim of this study was to examine the transferrin levels in the sera of these infants during their first few months of life.

\section{MATERIALS AND METHODS}

Transferrin was purified from a pool of outdated human blood by a modification of a method described previously (16). Eight hundred milliliters of plasma were diluted in the cold with $800 \mathrm{ml}$ $0.01 \mathrm{M}$ Tris- $\mathrm{HCl}, \mathrm{pH} 8.8$. Nonglobulin proteins were precipitated by the addition of $1,600 \mathrm{ml}$ of $0.6 \%$ Rivanol in $0.01 \mathrm{M}$ Tris- $\mathrm{HCl}$, $\mathrm{pH}$ 8.8. After 60 min Rivanol was removed from the supernatant fluid by vacuum filtration through a $400-\mathrm{ml}$ column of potato starch equilibrated previously with $0.01 \mathrm{M}$ Tris- $\mathrm{HCl}, \mathrm{pH} 8.8$. The effluent was concentrated to approximately $200 \mathrm{ml}$ by ultrafiltration and the $\gamma$-globulin fraction was precipitated by bringing the solution to $50 \%$ saturation with $\left(\mathrm{NH}_{4}\right)_{2} \mathrm{SO}_{4}$ at room temperature. The supernatant fluid was dialyzed exhaustively against distilled $\mathrm{H}_{2} \mathrm{O}$ at $4^{\circ}$ and then lyophilized.

The lyophilized material was dissolved in a small volume of borate-phosphate buffer, $\mathrm{pH} 8.2\left(11 \mathrm{mM} \mathrm{Na}_{2} \mathrm{~B}_{4} \mathrm{O}_{7} ; 16 \mathrm{mM}\right.$ $\mathrm{NaH}_{2} \mathrm{PO}_{4}$ ), the transferrin was saturated with iron using ferric citrate (2), and the solution was dialyzed against the borate-phosphate buffer and then applied to a column of DEAE-A50 Sephadex which had been equilibrated with the same buffer. After washing the column thoroughly with the starting buffer transferrin was eluted with $0.06 \mathrm{M} \mathrm{NaCl}$ in the borate-phosphate buffer. The transferrin solution was concentrated by ultrafiltration, dialyzed exhaustively against distilled $\mathrm{H}_{2} \mathrm{O}$, and lyophilized.

A single precipitin line was obtained with the transferrin by immunodiffusion and immunoelectrophoresis against rabbit antiserum (25) to whole human serum, thus establishing the purity of the transferrin preparation.

Rabbits were immunized by the intramuscular injection of 15 mg transferrin in complete Freund's adjuvant, followed 1 week later by the intramuscular injection of $25 \mathrm{mg}$ in complete Freund's adjuvant. Sera were collected 10 days after the last injection and were stored at $-20^{\circ}$. A single precipitin line was obtained with these antisera by immunodiffusion and immunoelectrophoresis against whole human serum.

Newborn and adult transferrin were shown to be antigenically identical by immunodiffusion studies.

Tranferrin concentrations in newborn sera were determined by the radial immunodiffusion procedure of Mancini et al. (15). Purified human transferrin and a pool of normal humant plasma were used as controls and for calibration curves.

Preterm and term infants whose birth weights were appropriate for gestational age were included in the study. The maternal 
menstrual history correlated with the gestational age of these infants as judged by physical examination. Although the infants were sampled at different postnatal ages, they were selected at birth for the study and showed no evidence of congenital anomalies or respiratory distress.

The transferrin determinations were done on portions of blood samples which were obtained for routine biochemical and hematologic examination.

\section{RESULTS}

The serum transferrin levels at birth and up to 8 weeks after birth for a group of early preterm newborn infants whose ages were equal to or less than 32 weeks are presented in Figure 1. For comparison the values for normal term infants and normal adults are also shown. At birth the concentration of transferrin in sera from the preterm infants were $45 \%$ of that found in normal term infant sera and $36 \%$ of the level in normal adult sera. The early preterm newborn infant's transferrin levels rise slowly so that 7-8 weeks after birth they are $78 \%$ of the level found in normal term infant sera and $63 \%$ of that in normal adult sera.

In another series of determinations, the serum transferrin concentrations at birth were compared with the gestational age of the infants. As shown in Figure 2 the level of transferrin in the sera of infants of $27-28,29-34$, and 35-38 weeks of gestational age were $41 \%, 56 \%$, and $80 \%$, respectively, of the concentration found in the sera from infants of $39-42$ weeks of gestational age.

It appears that the concentrations of transferrin in the sera of the infants which we studied were related to their postconceptional rather than their postnatal ages.

\section{DISCUSSION}

This study demonstrates clearly that early preterm newborn infants are hypotransferrinemic during the first postnatal months of life. Transferrin, the protein which transports iron in the body from the intestinal site of absorption and the sites of hemoglobin breakdown to the tissues requiring iron, as well as the various storage sites, has been shown to have bacteriostatic properties when not fully saturated with iron $(4-7,10,19,22)$.

Although there is no evidence that the late anemia of prematurity can be prevented by prophylactic iron $(3,9,13)$, several authors have suggested that low birth weight infants be placed on prophylactic iron $(8,11)$. Since the low birth weight infant has a lack of $\operatorname{lgG}$ and $\operatorname{lgM}$ antibodies (12), the prolonged hypotransferrinemia may be an additional defect in host defense against bacterial invaders, particularly if the transferrin is saturated with

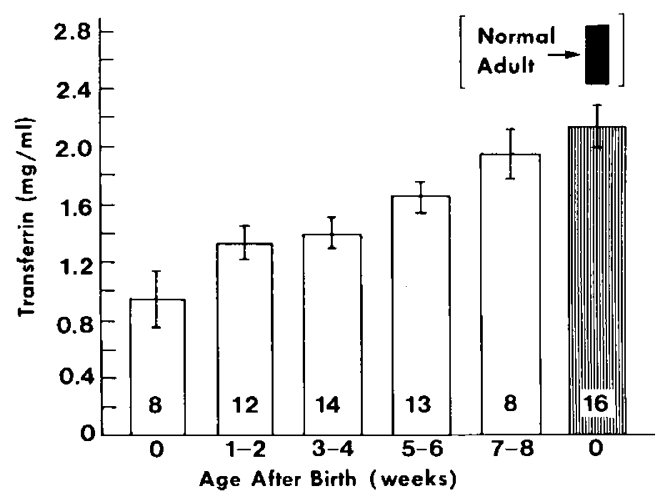

Fig. 1. Postnatal serum transferrin levels of early preterm newborn infants with a gestational age less than or equal to 32 weeks. The numbers within the bars refer to the number of infants in each group. The vertical lines represent the standard error of the mean. $\square$, early preterm newborn infants; 皿, normal term infants.

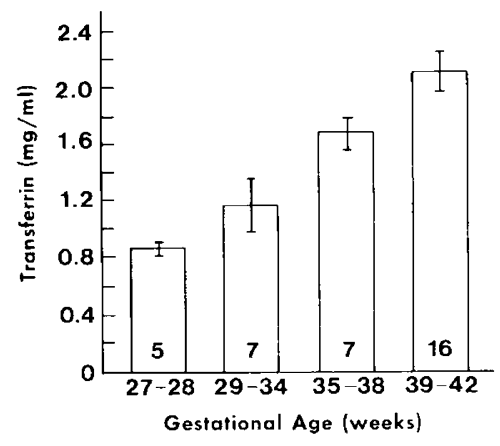

Fig. 2. Serum transferrin levels at birth for infants of different gestational ages. The numbers within the bars refer to the number of infants in each group. The vertical lines represent the standard error of the mean.

iron. Therefore, the rationale for the administration of prophylactic iron to the early preterm newborn infant may be questionable.

\section{SUMMARY}

Early preterm newborn infants are markedly hypotransferrinemic during their first few months of life postnatally. Their serum transferrin levels reflect their postconceptional rather than their postnatal ages.

\section{REFERENCES AND NOTES}

1. Aisen, P., and Leibman, A.: Citrate-mediated exchange of $\mathrm{Fe}^{3+}$ among transferrin molecules. Biochem. Biophys. Res. Commun., 32: 220 (1968).

2. Bates, G. W., Billups, C., and Saltman, P.: The kinetics and mechanism of iron (III) exchange between chelates and transferrin. I. The complexes of citrate and nitrilotriacetic acid. J. Biol. Chem., 242: 2810 (1967).

3. Buchanan, G. R., and Schwartz, A. D.: Impaired erythropoietin response in anemic premature infants. Blood, 44: 347 (1974).

4. Bullen, J. J., Leigh, L. C., and Rogers, H. J.: The effect of iron compounds on the virulence of $E$. coli for guinea pigs. Immunology, 15: 581 (1968).

5. Bullen, J. J., Rogers, H. J., and Lewin, J. E.: The bacteriostatic effect of serum on Pasteurella septica and its abolition by iron compounds. Immunology, 20:391 (1971).

6. Bullen, J. J., Wilson, A. B., Cushie, G. H., and Rogers, H. J.: The abolition of the protective effect of Pasteurella septica antiserum by iron compounds. Immunology, 14: 889 (1968).

7. Caroline, L., Rosner, F., and Kozinn, P. J.: Elevated serum iron, low unbound transferrin and Candidiasis in acute leukemia. Blood, 34: 441 (1969).

8. Committee on Nutrition: Iron-fortified formulas. Pediatrics, 47: 786 (1971).

9. Dallman, P. R.: Iron, vitamin E and folate in the preterm infant. J. Pediat., 85 . 742 (1974).

10. Fletcher, J.: The effect of iron and transferrin on the killing of $E$. coli in fresh serum. Immunology, 20: 493 (1971).

11. Fomon, S. J.: Infant Nutrition, Ed. 2, p. 315 (W. B. Saunders, Philadelphia, 1974).

12. Forman, M. L., and Stiehm, E. R.: Impaired opsonic activity but normal phagocytosis in low-birth-weight infants. N. Engl. J. Med., 281: 926 (1969).

13. Gorten, M. K., Hepner, R., and Workman, J. B.: Iron metabolism in premature infants. I. Absorption and utilization of iron as measured by isotope studies. J. Pediat., 63: 1063 (1963).

14. Katz, J. H.: Transferrin and its functions in the regulation of iron metabolism. In: A. S. Gordon: Regulation of Hematopoiesis, Vol. 1, p. 539 (Meredith, New York, 1970).

15. Mancini, G., Carbonara, A. O., and Heremans, J. F.: Immunochemical quantitation of antigens by single radial immunodiffusion. Immunochemistry, 2: 235 (1965).

16. Martinez-Medellin, J., and Schulman, H. M.: The kinetics of iron and transferrin incorporation into rabbit erythroid cells and the nature of stromal-bound iron. Biochim. Biophys. Acta, 264: 272 (1972).

17. Masawe, A. E. J., and Attenyi, J. R.: Serum protein and transferrin determinations to distinguish kwashiorkor from iron deficiency anaemia. Arch. Dis. Childhood, 48: 927 (1973).

18. McFarlane, H., Reddy, S., Adcock, K. J., Adeshina, H., Cooke, A. R., and Akene, J.: Immunity, transferrin, and survival in kwashiorkor. Brit. Med. J., 4: 268 (1970).

19. Rogers, H. J.: Bacteriostatic effects of horse sera and serum fractions on Clostridium welchii type $\mathrm{A}$ and the abolition of bacteriostasis by iron salts. Immunology, I2: 285 (1967).

20. Schade, A. L., and Caroline, L.: An iron-binding component of human blood plasma. Science, 104: 340 (1946). 
21. Sturgeon, P.: Studies of iron requirements in infants and children. I. Normal values for serum iron, copper, and free erythrocyte protoporphyrin. Pediatrics, 13: 107 (1954).

22. Weinberg, E. D.: Iron and susceptibility to infectious disease. Science, 184: 952 (1974).

23. Weinberg, E. D.: Roles of iron in host-parasite interactions. J. Infect. Dis., 124: 401 (1971).

Copyright $\odot 1976$ International Pediatric Research Foundation, Inc.
24. Weinberg, E. D.: Systemic salmonellosis: A sequela of sideremia. Texas Rep. Biol. Med., 30: 277 (1972)

25. Hyland Laboratories, Los Angeles, Calif:

26. Requests for reprints should be addressed to: H. M. Schulman, Lady Davis Institute for Medical. Reseanch, Jewish General Hospital, 3755 Cote St. Catherine Rd. Montreal', Quebec H3T IEZ(Canada).

27. Accepted for publication September 30, 1975 :

Pediat. Res. 10: 120-126 (1976)

Lymphocytic leukemia mortalai phenomenon peripheral blood

Printed in U.S.A

\title{
Morula Forms of E Rosettes: Distribution, Specific Inhibition, and Enhancement
}

\author{
SHIH-WEN HUANG, ${ }^{(23)}$ THOMAS BARBER, M. DAVID POULIK, AND RICHARD HONG \\ Departments of Pediatrics and Pathology and the Immunobiology Research Center, University of Wisconsin, Center \\ for Health Sciences, Madison, Wisconsin, and Department of Immunochemistry, Wayne State School of Medicine, \\ Detroit, Michigan, USA
}

\begin{abstract}
Extract
Rosette-forming cells (RFC) with more than 10 sheep red blood cells (SRBC's) per cell defined as morula-forming cells (MFC) were studied in human lymphoid organs and in the peripheral blood (PBL). MFC are most common in the thymus (more than $50 \%$ ) and the frequency is much less in peripheral lymphoid tissuesi and in the blood (29.8\% in those less than 5 years old; $14.9 \%$ in aduts). There is very slight decrease in total $\mathrm{RFC}$ in PBL over age 5, but the changes in MFC are quite striking. Treatment with antihuman thymus antiserum (ATS) and with anti-human lymphoblastic antiserum (ATL) resulted in significant inhibition of total rosette and morula rosette formation. No inhibition was seen using normal brain antiserum, anti-IgM antiserum, or anti-L chain antiserum. In two patients with chronic lymphocytic leukemia and in some cases of thymic deficiency the ratio of MFC to total RFC was unusually high. After culture with phytohemagglutinin (PHA) and conversion to blast forms of after surface peturbation by papain or freeze-thaw treatment, MFC numbers were increased.
\end{abstract}

\section{Speculation}

The reason that $T$ cells bind SRBC without prior sensitization remains a mystery. Nevertheless, the reaction serves as a reliable detector of a special class of immunologically competent lymphocytes. Subpopulations within the two major classes of human lymphocytes (B and $T$ cells) are now known. We speculate that an analysis of surface markers may help to detect these subclasses. We suggest that the more primitive $T$ cells may stiow the phenomenon of morula formation. It is postulated that the increase in MFC's might be due to the exposure of hidden sites or alteration of pre-existing surface receptors.

Thymus-derived human peripheral blood lymphocytes are known to form rosettes spontaneously with SR BC $(4-7,11,15,16$, $18,25-27)$. The highest number of RFC are found in thymuses (11,
15, 18, 25, 27), and significantly low RFC have been reported among patients. with defective $T$ cell immunity $(4,9,15,21,25,26)$.

In studying human lymphoid cells, we have observed some rosettes with extremely large numbers of surrounding $\mathrm{SRBC}$. If those cells with more than $10 \mathrm{SRBC}$ adherent are enumerated separately, different patterns of distribution in various lymphoid organs as well as in disease states are observed. We have termed the cells which have clusters of many surrounding SRBC the MFC. The number 10 was chosen since $10 \mathrm{SRBC}$ 's will usually completely surround a lymphocyte. It was the purpose of this study to further characterize the morula phenomenon by noting distribution patterms in age and disease, by ultrastructural studies, and by observing the effect on monula formation of prior cell treatment with: various antisera, PHAl. papain, freezing and thawing, hypotonic treatment, or short term in vitro culture.

\section{MATERIALS AND METHODS}

\section{FOR'MATION OF ROSETTES}

The method was essentially that of Jondal et al. (15) with minor modifications. Peripheral blood mononuclear leukocytes were isolated from heparinized venous blood by Ficoll-Hypaque gradient centrifugation. Lymphocytes from tonsils, lymph nodes, livers, spleens, and thymuses were prepared'by. gentle teasing of fresh tissues and suspension in minimum essential medium (MEM) (29) with Hank's salts. The source of lymphoid tissue was fetal (30) or surgical specimens; all specimens were normal histologically. Rosettes were prepared by adding: $0.2 \mathrm{ml}$ leukocyte suspension in MEM $\left(4 \times 10^{6} / \mathrm{ml}\right)$ to $0.25 \mathrm{ml}$ of $0.5 \% \mathrm{SRBC}$ in MEM. Cells were mixed thoroughly and incubated at $37^{\circ}$ for $5 \mathrm{~min}$. The mixture was then centrifuged at $200 \times g$ for $5 \mathrm{~min}$ at room temperature and incubated at $4^{\circ}$ for $1-2 \mathrm{hr}$. The cell pellet was resuspended very gently by rocking the tubes. Ten microliters of $0.1 \%$ eosin dye were added to the final cell suspension. At least 200 lymphocytes were counted in a hemocytometer and all lymphocytes binding more than three SRBC were considered to be rosettes. The rosettes were further classified as low binding if less than $10 \mathrm{SRBC}$ adhered to a 